\title{
Alternative Selection in Reducing Wood Scrap with Green Productivity Approach
}

\author{
Dini Wahyuni ${ }^{1, *}$, Irwan Budiman ${ }^{2}$, and Mangara Tambunan ${ }^{1}$ \\ ${ }^{1}$ Department of Industrial Engineering, Faculty of Engineering, Universitas Sumatera Utara, Medan - Indonesia \\ ${ }^{2}$ Department of Industrial Engineering, Faculty of Engineering, Universitas Prima Indonesia, Medan - Indonesia
}

\begin{abstract}
This research was conducted in companies engaged in the production of furniture in North Sumatra. From observations made, seen piles of scrap pieces of wood from the rest of the production. This study was conducted to select the best alternative to reduce scrap wood with green productivity approach so that productions are going to more economical and productive. Green productivity approach to the reduction of scrap is performed by calculating Green Productivity Index. There are 3 alternative wood scrap reduction, which is: (1) Do not perform any conversion actions; (2) Wood scrap smoothed and pressed into the pressed wood as the "content" of the door, wood scrap that is usually used as a fuel in the boiler is replaced with oil palm pulp; and (3) Purchase the woods with appropriate size and produces scrap as minimum as possible. Alternative 2 was selected as the best alternative to the Green Productivity Index (GPI) Human amounted to 1, GPI Material 1.13, GPICapital1.06, GPI Energy at 1.16, and GPI Waste of 0.
\end{abstract}

Keywords: Green productivity; financial analysis; scrap; alternative selection

\section{Introduction}

This research was conducted in wooden furniture company that produces a variety of products such as doors, drawer table, and chairs. The focus of this research is the door product as the main product. In the production, the company is using wood as the main material. Wood materials obtained from Sumatra and from outside Sumatra. During observations in the field, see the buildup of wood scrap by 3.5 tons per month. Some $45 \%$ of scrap wood is used for heating the boiler so the amount of scrap which still accumulates is about $55 \%$ in each month.

Green Productivity provides the basic needs of the business to be able to combine environmental focus and also economic performance in the repairing process. Green Productivity developed a conversion process to help businesses understand customer needs about more environmentally friendly products. [1-4]

Implementation of green productivity in plantation business can increase productivity to $18,18 \%$ by turning fruit bunch of palm oil solid waste into liquid smoke [5], compost [6], and pellet [7], so that waste can be minimized and cleaner production. Improving Green Productivity could be done by reducing emissions released to th air such as $\mathrm{CO}_{2}$ intensity [8]. It could be the input in making policy to develop economic and environment in Indonesia [9]. Implementation of Green Productivity Growth in China was done by Feng Tao et al. In 3 urban agglomerations, the result shows the differences determinant across them and efficiency change is less benefit than the clinical change [10]. In
China, research on Green Economy Performance and Green Productivity Growth in cities observed shows that the value of performance and productivity can still be improved. There are gaps between regions and recommendations for improvement [11]. In another research shown that implemented energy conservation policies in China manufacturing sector are not optimal and more stringent enforcement would impact to a better green productivity growth in the manufacturing sector [12-13].

Woods is a material whose production requires a long time, Woods is also one material that is difficult to obtain, therefore, the results of this research are expected to obtain an effective way of scrap reduction by using green productivity approach to be utilized optimally. With the application of Green Productivity, it will be able to reduce quality of environment in a long time, especially to reduce carbon emissions to the surrounding environment.

\section{Method}

Green Engineering or Green productivity has four general aims to improve quality of the environment and economic value when implemented on the production floor, namely Reduction of Waste, Good Management of Materials, Prevent Pollution generation, and Enhance the Product [2].

Green Productivity steps include: [2]

1. Identify the problem

2. Determining Targets that need to achieve

* Corresponding author: diniwahyuni2015@gmail.com, 
3. Proposed alternative problem-solving

4. Selection of the best alternatives

5. Feasibility Calculation

6. Trial and implementation in small-scale

7. Regular meeting and troubleshooting

8. Follow-up and accountability

9. Allocate resources

10. Management support needed

11. Review and evaluation of the result

12. Collect and analysis existing and developing condition

Problem identification can be done using eco mapping, describes the process flow diagram and make the material balance or energy balance. Ecomapping is a visual tool, which is simple and practical for analysis, control, and information on the environmental performance of the company. Material balance is a tool that provides a quantitative assessment of the input and output material. Material balance development for environmental management program based on the Process Flow Diagram.

An input to the process in an operation unit can be in the form of raw materials, chemicals, water, air, and energy. The output as primary products, by-product, rejected products, waste liquid, and waste gas. Waste can be stored in the disposal unit or reuse. Material balance used to assess the energy in order to obtain energy balance [14-18].

Targets determined beforehand, then raised a number of alternatives for the solution of the problems encountered. Selection of the best alternatives is done using the Green Productivity Index (GPI), namely GPI Human, GPI Capital, GPI Material, GPI Energy and GPI Waste. GPI Humanise an index indicating the result of the input from its workforce. GPI Capital is an index indicating the result of the input of capital owned by the company. Material GPI is an index that shows the results of the input material. GPI Energy is an index indicating the result of the energy input. Waste GPI is an index that shows the results of the waste. GPI is calculated using the formula:

$$
\mathrm{GPI}_{\text {factor }}=\frac{\text { Output }}{\text { Input }_{\text {factor }}}
$$

The factors are the human, capital, material, energy, or waste.

\section{Results and Discussion}

\subsection{Proposed Alternative of Problem Solution}

In this study considered three alternatives that can be taken to resolve the problem, that first alternative which does not do any conversion, that means continuing the existing condition of the company today. The second alternative which is a focus of the problem solving is done by reprocessing of the scrap (reuse and recycle) into material that can be used for the production process. While the third alternative is more focused on early prevention of the occurrence of scrap (reduce). The problem-solving description can be seen in Table 1 .

To apply the second alternative there are two big things that need to be done by the company which is purchases of wood crusher machine and press machine. In addition, the company needs to maintain continuity of supply of the palm oil residue as a substitute fuel.

\subsection{Selection of the best alternative}

Calculations of factor productivity are presented in Table 2 and Green Productivity index (GPI) is shown in Table 3. The alternative choice is based on the value of Green Productivity Index, which takes into calculations of the output and input. As shown in Table 3, for Human factors, Material, Capital, Energy, and Waste; seen that Alternative 2 is the best alternative because of the GPI value always better than the other alternatives (Greater the GPI value means the better, except for GPI waste that the smaller the value means the better).

Expenses arising from each alternative and the output obtained are listed in Table 2 below.

\begin{tabular}{|c|c|c|}
\hline Alternative 1 & Alternative 2 & Alternative 3 \\
\hline $\begin{array}{ll}\text { - } & \begin{array}{l}\text { Do not make } \\
\text { changes }\end{array} \\
\text { - } & \text { (existing } \\
\text { condition) }\end{array}$ & $\begin{array}{l}\text { - Utilization of scrap by forming a scrap into a woods board that can } \\
\text { be cut and used in production. } \\
\text { - Purchase of wood crusher machine (cutting machine and wood } \\
\text { shredder) to destroy the scrap for easily processed. } \\
\text { - Purchase of press machine to form sawdust into wood boards that } \\
\text { will be used for the material in the production. } \\
\text { - Changing the woods that commonly used for heating by using palm } \\
\text { oil pulp. } \\
\text { - In the cutting machine, the measures for each panel has been marked } \\
\text { in order to facilitate the employees in the production process. }\end{array}$ & $\begin{array}{l}\text { Purchase the woods whose } \\
\text { the size is in accordance with } \\
\text { the size of the product design. } \\
\text { Changing the wood used in } \\
\text { heating by using palm oil } \\
\text { pulp. } \\
\text { On mowers, the measures for } \\
\text { each panel has been marked } \\
\text { in order to facilitate the } \\
\text { employees in the production } \\
\text { process }\end{array}$ \\
\hline
\end{tabular}


Table 2. Summary of Costs in Each Alternative

\begin{tabular}{|c|c|c|c|}
\hline Output & Alternative 1 & Alternative 2 & Alternative 3 \\
\hline \multicolumn{4}{|l|}{ Finished Product } \\
\hline Total & 6,362 & 7,138 & 6,521 \\
\hline Price/units & 450,000 & 450,000 & 450,000 \\
\hline Total Output & $2,862,900,000$ & $3,212,100,000$ & $2,934,450,000$ \\
\hline \multicolumn{4}{|l|}{ Input } \\
\hline \multicolumn{4}{|l|}{ 1. Human Input } \\
\hline Total & 32 & 36 & 33 \\
\hline Salaries/person (IDR) & $1,400,000$ & $1,400,000$ & $1,400,000$ \\
\hline H & $44,800,000$ & $50,400,000$ & $46,200,000$ \\
\hline \multicolumn{4}{|l|}{ 2. Material Input } \\
\hline Total (tons) & 50.9 & 50.9 & 50.9 \\
\hline Price/ton & $50,000,000$ & $50,000,000$ & $50,000,000$ \\
\hline M & $2,545,000,000$ & $2,545,000,000$ & $2,545,000,000$ \\
\hline \multicolumn{4}{|l|}{ 3. Capital Input } \\
\hline Total capital & $15,000,000$ & $15,907,000$ & $15,000,000$ \\
\hline $\mathrm{C}$ & $15,000,000$ & $15,907,000$ & $15,000,000$ \\
\hline \multicolumn{4}{|l|}{ 4. Energy Input } \\
\hline a. Total scrap (kg) & 2,794 & 2,947 & 2,947 \\
\hline Price $/ \mathrm{kg}$ & 1,100 & 75 & 75 \\
\hline b. kWh of electricity & 54,000 & 55,872 & 54,000 \\
\hline $\mathrm{kWh}$ price & 800 & 800 & 800 \\
\hline $\mathbf{E}$ & $46,273,400$ & $44,918,625$ & $43,421,025$ \\
\hline \multicolumn{4}{|l|}{ 5. Waste } \\
\hline Amount (kg) & 3,415 & 5 & 5,090 \\
\hline Price $/ \mathrm{kg}$ & 1,100 & 1.100 & 1,100 \\
\hline W & $3,756,500$ & 5.500 & $5,599,000$ \\
\hline
\end{tabular}

Table 2 shows that the value of the human input and the capital of alternative 2 is the largest compared to the alternatives 1 and 3. While the value of the energy input and waste for alternative 2 is moderate (between alternative 1 and alternative 3). Material input values for the three alternatives are of the same size. On the other hand, the output value of alternative 2 is much larger than the output value of alternative 1 and alternative 3, so from the value of the input and output is seen that alternative 2 is much better than the other alternatives. Partial productivity index of each alternative is shown in Table 3 below.

Table 3. Indicators to Green Productivity

\begin{tabular}{|l|c|c|c|c|c|c|}
\hline $\begin{array}{c}\text { GREEN } \\
\text { PRODUCTIVITY } \\
\text { INDICATORS }\end{array}$ & $\begin{array}{c}\text { Existing } \\
\text { Condition } \\
\text { (first } \\
\text { alternative) } \\
\text { GP Ratio }\end{array}$ & $\begin{array}{c}\text { Existing } \\
\text { Condition } \\
\text { (first } \\
\text { alternative) } \\
\text { GP Index }\end{array}$ & $\begin{array}{c}\text { Second } \\
\text { alternative } \\
\text { GP Ratio }\end{array}$ & $\begin{array}{c}\text { Second } \\
\text { alternative } \\
\text { GP Index }\end{array}$ & $\begin{array}{c}\text { Third } \\
\text { alternative } \\
\text { GP Ratio }\end{array}$ & $\begin{array}{c}\text { Third } \\
\text { alternative } \\
\text { GP Index }\end{array}$ \\
\hline GP Human Ratio & 63.90 & 1 & 63.73 & 1.00 & 63.52 & 0.99 \\
\hline GP Material Ratio & 1.12 & 1 & 1.26 & 1.13 & 1.15 & 1.03 \\
\hline GP Modal Ratio & 190.86 & 1 & 201.93 & 1.06 & 195.63 & 1.02 \\
\hline GP Energy Ratio & 61.87 & 1 & 71.51 & 1.16 & 67.58 & 1.09 \\
\hline GP Waste Ratio & 0.07 & 1 & 0.00 & 0.00 & 0.10 & 1.43 \\
\hline
\end{tabular}

From the Table 3, shows that the values of Green Productivity Ratio and GPI value for alternative 2 always better than the alternative 1 and alternative 3 for each factor studied (human, material, capital, energy, and waste).

\subsection{Discussion}

An effective way to reduce scrap is the second alternative, which proposed the addition of wood crusher machine and press machine to process scrap in the factory with destroying the scrap into sawdust. After that, pressing the sawdust to form the beams with certain sizes. The beams will be used to form the central part (core) of the wooden door. Thus, the use of woods will be more effective. Procurement of the new machines requires no additional land space because it can be placed in material build-up areas.

From a review of alternative 2 was obtained that the Green Productivity Index (GPI) for Human at 1 which did not show any significant changes to the implementation of these alternatives on labor, GPI Material at 1.13 indicate an improvement in productivity in the use of materials, GPI Capital at 1.06 also indicates 
a productivity improvement can be obtained in terms of capital, GPI energy at 1.16 which shows that energy use is more productive than the actual situation, and GPI waste close to 0 which indicates that the waste produced is reduced.

Besides the value of GPI, the best alternative remains to be seen from the social and environmental aspects.

\section{Conclusion}

From this study, can be concluded that the best alternative in the reduction of wood scrap with Green Productivity approach is alternative 2 because it has a better Green Productivity Index than the other alternatives.

\section{References}

1. Alarilla, Maria and Jilla Decena. Green Productivity Initiatives: Intel Malaysia's Experience and Perspectives. Corporate Social Responsibility in Asia (2009).

2. Asian Productivity Organization. 2006. Handbook on Green Productivity. Canada.

3. Graedel, Thomas E. and Jennifer A. HowardGrenville. Greening the Industrial Facility. USA: Springer. (2004)

4. Singgih, Moses L. Penerapan Green Productivity pada Pabrik Pengolahan dan Pendinginan Ikan. (2011)

5. Nazaruddin Matondang, Productivity improvement with green approach to palm oil factory productivity, IOP Conf. Ser .: Mater. Sci. Eng., 309 (012065) (2018).

6. Bambang Trisakti, Jeni Lubis, Teuku Husaini, and Irvan, Effect of turning frequency on composting of empty fruit bunches mixed with activated liquid organic fertilizer, IOP Conf. Ser: Mater. Sci. Eng., 180 (012150) (2017).
7. Irvan, Processing of palm oil mill wastes based on zero waste technology, IOP Conf. Ser: Mater. Sci. Eng., 309 (012136) (2018).

8. The Ministry of Environment of the Republic of Indonesia. Emisi Gas Rumah Kaca dalam Angka. (2009)

9. Wawan Rusiawan, Prijono Tjiptoherijanto, Emirhadi Suganda, Linda Darmajanti, Assessment of green total factor productivity impact on sustainable Indonesia productivity growth, J. Procedia Environmental Sciences,28, pp. 493-501 (2015)

10. Feng Tao, Huiqin Zhang Xiaohua Xia, Decomposed Sources o Green Productivity Growth for Three Major Urban agglomerations in China, J. Energy Procedia, 104, pp. 481-486 (2016)

11. Jianglong Li, Lin Boqiang, Green economy, performane and green productivity growth in China's Cities: measures and policy implication, $J$. Sustainability, 8 (947), pp. 1-21 (2016)

12. Ke Li, Boqiang Lin, Impact of energy conservation policies on the green productivity in China's manufacturing sector: Evidence from a three-stage DEA models, J. Applied Energy, 168, pp. 351-363 (2016)

13. Singgih, Moses L, Mokh Suef, and Chandra Adi Putra. Waste Reduction with Green Productivity Approach for Increasing Productivity. (2010)

14. Heinz Werner Engel. Ecomapping. International Network for Environmental Management (INEM). (2002)

15. Ginting, Rosnani. Sistem Produksi. Yogyakarta: Graha Ilmu. (2007)

16. Sutalaksana, Iftikar Z, Ruhana Anggawisastra, and Jann H. Tjakraatmadja. Teknik Tata Cara Kerja.Bandung: ITB. (1979)

17. Aritonang, Robert, and Dian Anggraini. Upaya Pengelolaan Limbah Industri PT TEL Pulp and Paper (2011).

18. Khane, Abd-El Rahman. Manual for the Preparation of Industrial Feasibility Studies. UNIDO. 